\title{
ON THE INFLUENCE OF DIET ON THE RETENTION TIME OF FOOD IN THE DIGESTIVE TRACT OF COWS
}

\author{
AARNE MÄKELÄ \\ with technical assistance from LiISA LIAKKA \\ Department of Animal Husbandry, University of Helsinki
}

Received December 4, 1959

In their earlier investigations PALOHEImo and MÄKELÄ (2) and MäKELÄ (1, p. 84) have studied the rate of the passage of food in the digestive tract of cows hay being the only food. Palohermo and Mäkelä (3) have continued these experiments with cows fed on hay and concentrates in the ratio of either $1: 0.5$ or $1: 1$. The present paper deals with experiments with cows fed on either hay + sugar beet pulp or hay + swedes (rutabagas), in both cases in a ratio of $1: 0.5$ on a dry matter basis.

MÄKELÄ (1, p. 26) has reviewed until the year 1955 investigations related to the rate of passage of food in the digestive tract of farm animals. Palohermo and MÄKELÄ (3) have paid attention to some recent investigations made with ruminants and also to some earlier papers related to the transport of concentrates or other fine ground materials in the alimentary canal of ruminants and their influence upon the rate of passage of the whole ration. They have also paid attention to the various ways of expressing the retention time of food in the digestive tract.

In the present paper the retention time of food in the digestive tract of cows is calculated according to the principle used in the earlier papers cited above. For instance, as an expression for the retention time of dry matter in the reticulo-rumen the concept sthe mean retention time of a dry matter point", or, as shortened "the mean retention time of dry matter" has been used. That means the average time which the dry matter points ${ }^{1}$ ) of the ingesta stay in the said proventriculi, and it is calculated by dividing the dry matter contents in the reticulo-rumen by the daily intake of dry matter. Also for lignin, membrane substances (as a complex), and valuable $\mathrm{N}$-free nutrients, the retention time in the reticulo-rumen as well

1) The word "point" is used in the same sense as the point mass concept in physics. 
as the retention time of lignin in the whole digestive tract and in the digestive tract after passing the reticulo-rumen have been calculated according to the said principle. The term "the valuable $\mathrm{N}$-free nutrients" means $\mathrm{N}$-free organic substances which are not included in the complex of membrane substances. To this fraction belong, besides the lipids, the cell enclosure carbohydrates together with the pectines and some other readily hydrolysable cell wall substances $(4$, p. 1$)$.

As in the earlier experiments cows assigned to be removed from the herd of the University farm were used. The animals were in perfect health as regards digestion. They were fed on the experimental rations for at least 10 days. The food was given in 3 equal rations at 5, 13, and 21 o'clock. After this period of fairly evenly spaced feeding the cows were slaughtered. The slaughtering always occurred at 9 a.m., half-way between two feeding times. The contents of the different parts of the alimentary canal were weighed and sampled.

Five cows received in addition to hay fresh sugar beet pulp, and eight cows swedes. A small amount $(0.2-0.3 \mathrm{~kg}$ per day) of soybean meal was given so as to ascertain the access to protein. On both diets the quantities of pulp, swedes, and soybean meal were so allotted that the cows received the same percentages of dry matter in these foods as the cows in the previous experiments had received in the form of concentrates, i.e. about $35 \%$ of the dry matter of the whole ration. This

Table 1. The enumeration of experimental animals and some fundamental data pertaining to the experiments.

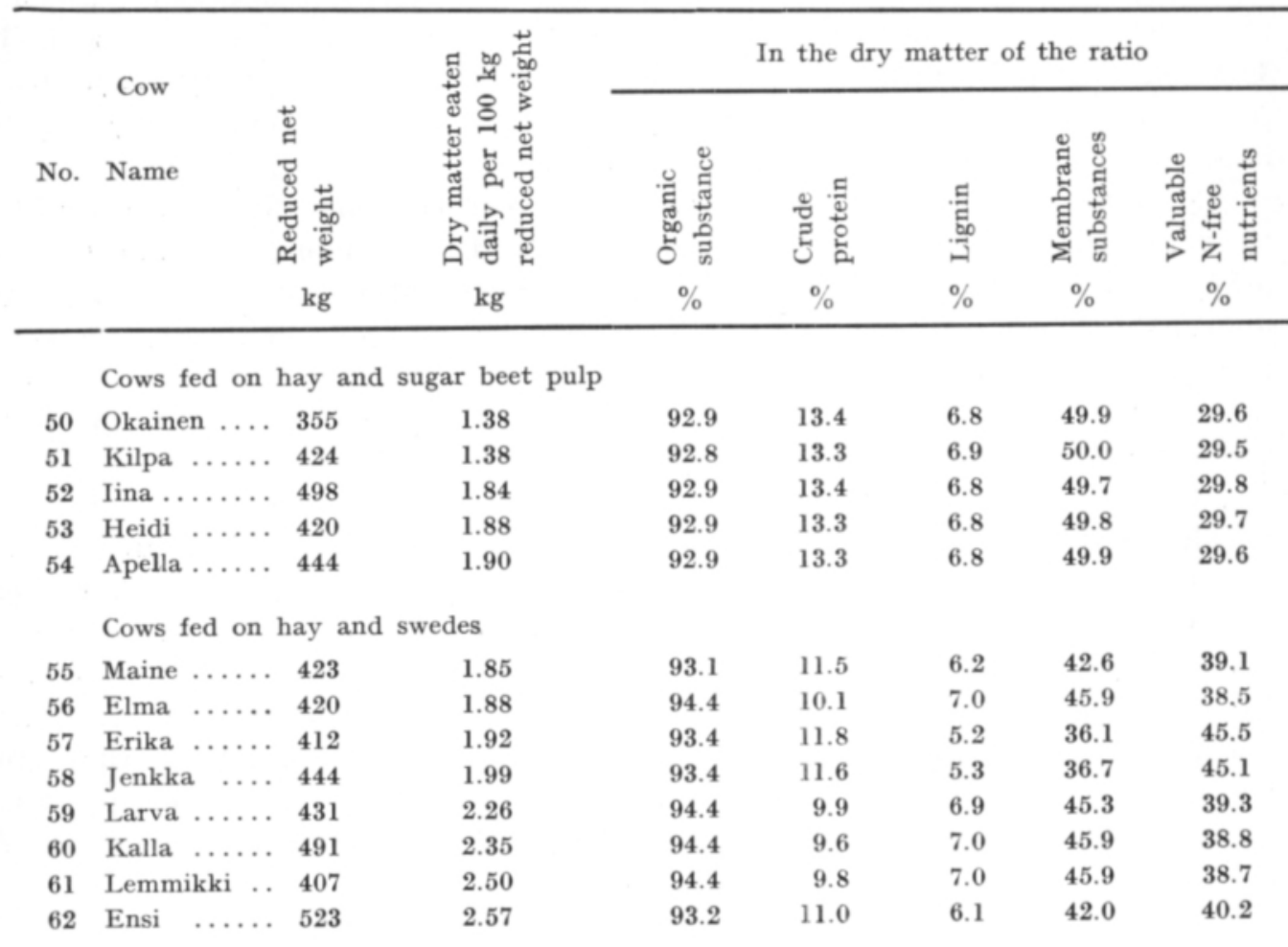


Table 2. The amounts of the fresh contents in the different parts of the digestive tract.

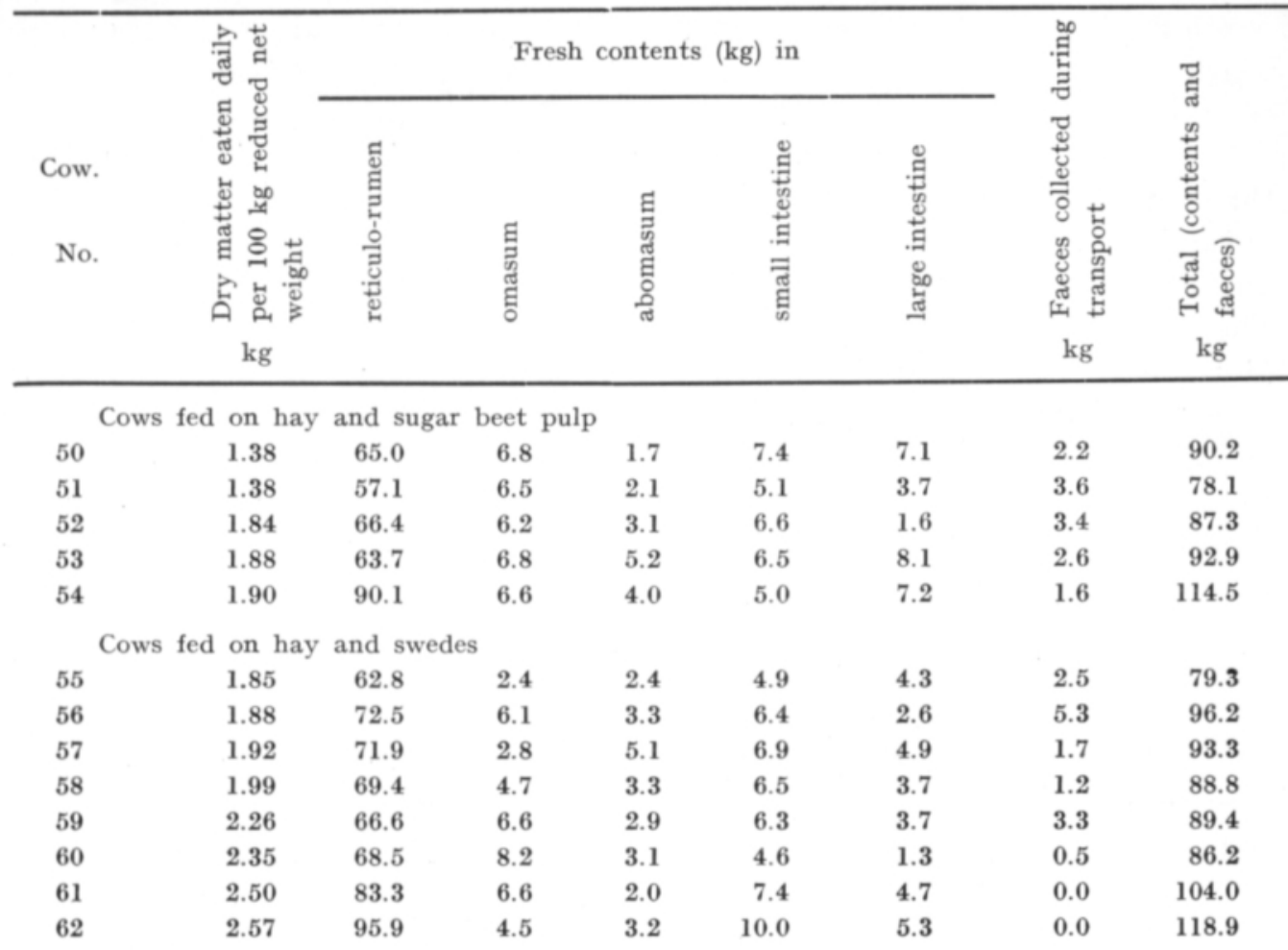

Table 3 a. Data concerning the composition of the contents in the stomachs.

\begin{tabular}{|c|c|c|c|c|c|c|c|c|c|c|c|c|c|c|c|}
\hline \multirow{3}{*}{ Cow } & \multirow{3}{*}{ 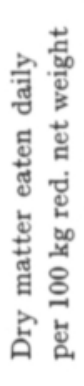 } & \multicolumn{6}{|c|}{ Contents of reticulo-rumen } & \multicolumn{4}{|c|}{ Contents of omasum } & \multicolumn{4}{|c|}{ Contents of abomasum } \\
\hline & & & \multicolumn{5}{|c|}{$\%$ in dry matter } & \multirow[b]{2}{*}{ 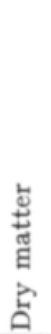 } & \multicolumn{3}{|c|}{$\%$ in dry matter } & \multirow[b]{2}{*}{ 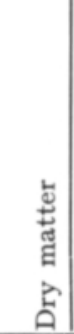 } & \multicolumn{3}{|c|}{$\%$ in dry matter } \\
\hline & & 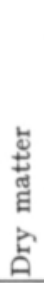 & 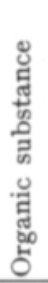 & $\begin{array}{l}\frac{1}{8} \\
8 \\
0 \\
0 \\
0 \\
0 \\
0\end{array}$ & 咅 & 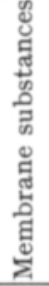 & 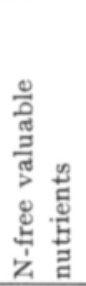 & & 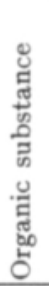 & 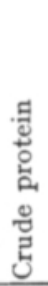 & 豆 & & 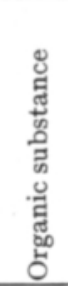 & 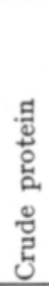 & 点 \\
\hline
\end{tabular}

Cows fed on hay and sugar beet pulp

\begin{tabular}{|c|c|c|c|c|c|c|c|c|c|c|c|c|c|c|c|}
\hline 50 & 1.38 & 11.0 & 87.1 & 14.3 & 13.4 & 56.7 & 16.1 & 15.3 & 89.0 & 17.4 & 17.3 & 14.8 & 65.2 & 13.2 & 9.7 \\
\hline 51 & 1.38 & 12.0 & 90.9 & 15.6 & 13.0 & 58.5 & 16.8 & 19.3 & 90.1 & 18.1 & 16.7 & 11.7 & 58.3 & 17.2 & 8.2 \\
\hline 52 & 1.84 & 13.6 & 90.6 & 16.4 & 12.9 & 56.9 & 17.3 & 19.1 & 89.2 & 18.6 & 15.7 & 22.4 & 31.2 & 8.1 & 5.3 \\
\hline 53 & 1.88 & 12.0 & 90.0 & 16.8 & 12.4 & 54.0 & 19.2 & 20.6 & 62.5 & 14.1 & 10.9 & 8.2 & 68.6 & 13.5 & 8.7 \\
\hline 54 & 1.90 & 10.2 & 89.4 & 16.7 & 13.7 & 53.0 & 19.7 & 16.6 & 86.7 & 20.4 & 16.2 & 13.2 & 51.1 & 13.9 & 8.2 \\
\hline \multicolumn{16}{|c|}{ Cows fed on hay and swedes } \\
\hline 55 & 1.85 & 10.8 & 88.7 & 15.8 & 12.0 & 53.3 & 19.6 & 16.2 & 87.5 & 17.4 & 15.3 & 8.1 & 84.8 & 21.1 & 11.8 \\
\hline 56 & 1.88 & 11.4 & 91.1 & 13.2 & 12.5 & 60.2 & 17.7 & 18.2 & 89.5 & 16.5 & 15.1 & 8.8 & 81.5 & 18.7 & 12.6 \\
\hline 57 & 1.92 & 10.2 & 88.6 & 18.2 & 11.3 & 50.4 & 20.0 & 16.5 & 87.8 & 24.5 & 13.6 & 10.5 & 66.3 & 17.0 & 11.0 \\
\hline 58 & 1.99 & 10.3 & 89.6 & 16.9 & 11.6 & 52.4 & 20.3 & 16.5 & 87.4 & 22.2 & 14.4 & 11.6 & 63.3 & 17.0 & 9.9 \\
\hline 59 & 2.26 & 12.0 & 91.9 & 12.2 & 11.8 & 63.3 & 16.4 & 17.3 & 91.6 & 14.7 & 13.7 & 14.1 & 61.2 & 13.3 & 8.5 \\
\hline 60 & 2.35 & 14.6 & 92.3 & 14.0 & 12.6 & 58.9 & 19.4 & 17.8 & 91.5 & 17.8 & 14.4 & 13.3 & 67.3 & 14.0 & 9.8 \\
\hline 61 & 2.50 & 12.2 & 91.6 & 13.2 & 12.6 & 59.5 & 18.9 & 18.1 & 90.3 & 15.7 & 14.6 & 9.0 & 76.9 & 21.0 & 11.1 \\
\hline 62 & 2.57 & 11.1 & 89.4 & 15.9 & 11.4 & 53.7 & 19.8 & 17.3 & 88.7 & 19.3 & 14.4 & 11.1 & 72.4 & 14.9 & 9.0 \\
\hline
\end{tabular}


arrangement was followed on both diets except for two cows on a hay +swede diet, which received swede dry matter $44 \%$. This circumstance had, however, no noteworthy influence on the results except on some quotas of retention times. Therefore the results of these two cows have been included in the subject matter.

On the basis of the amount of dry matter eaten the cows were divided into three goups, in which the quantities of dry matter eaten daily were $1.4 \mathrm{~kg}, 1.8-2.0$ $\mathrm{kg}$, and $2.3-2.6 \mathrm{~kg}$ per $100 \mathrm{~kg}$ reduced net weight. The corresponding feeding levels are accordingly called the scanty, the medium abundant, and the abundant feeding. The method of calculation of the reduced net weight is described in an earlier paper $(3$, p. 6). The above classes are found also in the earlier experiments with cows fed on hay and concentrates. Two of the cows on the hay +sugar beet pulp diet belonged to the scanty and three to the medium abundant feeding group. The latter cows were fed almost ad lib. The cows on the hay +swede diet belonged to the medium abundant feeding and the abundant feeding groups, four in each. The cows were fed almost ad lib.

Table $3 \mathrm{~b}$. Data concerning the composition of the contents in the intestines and the faeces

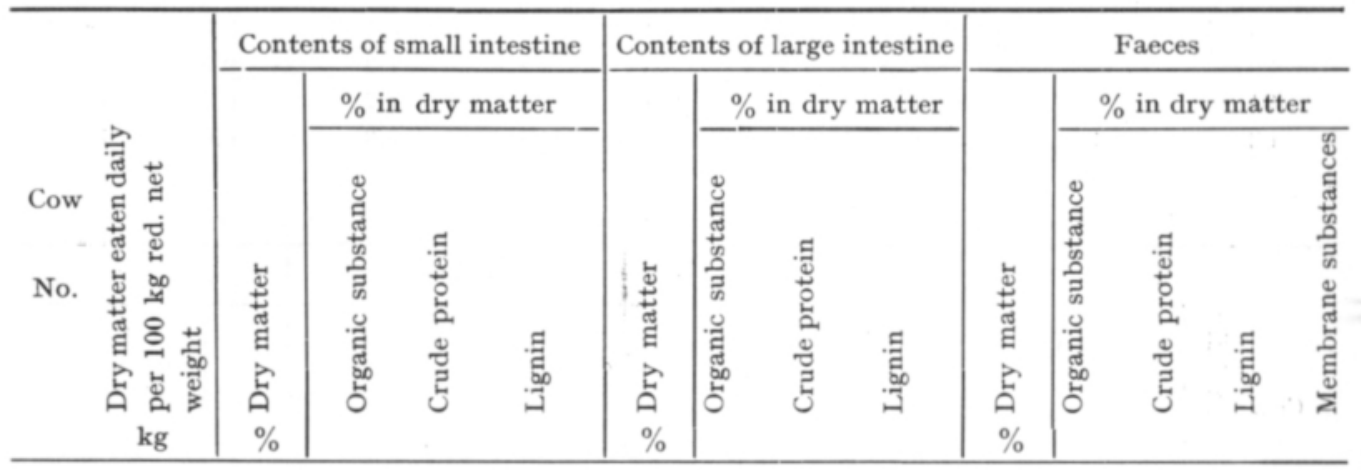

Cows fed on hay and sugar beet pulp

\begin{tabular}{|c|c|c|c|c|c|c|c|c|c|c|c|c|c|}
\hline 50 & 1.38 & 6.4 & 83.6 & 32.2 & 8.6 & 9.6 & 84.4 & 14.7 & 17.8 & 15.5 & 88.5 & 13.3 & 20.0 \\
\hline 51 & 1.38 & 8.2 & 85.0 & 26.9 & 10.3 & 10.6 & 86.0 & 14.3 & 17.5 & 16.9 & 89.0 & 12.5 & 19.8 \\
\hline 52 & 1.84 & 7.8 & 84.3 & 30.6 & 7.9 & 13.0 & 79.5 & 14.1 & 15.1 & 16.2 & 88.5 & 12.6 & 18.4 \\
\hline 53 & 1.88 & 7.7 & 83.9 & 32.7 & 7.6 & 9.9 & 82.9 & 12.4 & 16.5 & 13.2 & 85.7 & 13.0 & 18.4 \\
\hline 54 & 1.90 & 8.7 & 85.2 & 41.5 & 6.4 & 9.8 & 83.8 & 14.9 & 17.7 & 13.0 & 86.9 & 13.7 & 19.6 \\
\hline
\end{tabular}

Cows fed on hay and swedes

\begin{tabular}{|c|c|c|c|c|c|c|c|c|c|c|c|c|}
\hline 1.85 & 6.9 & 82.4 & 30.4 & 8.0 & 7.9 & 83.2 & 12.2 & 15.7 & 12.2 & 86.3 & 12.2 & 19.5 \\
\hline 1.88 & 7.5 & 83.3 & 21.6 & 10.7 & 10.8 & 83.9 & 11.6 & 17.4 & 14.7 & 87.0 & 10.0 & 18.6 \\
\hline 1.92 & 7.1 & 81.8 & 32.3 & 7.5 & 9.5 & 82.3 & 14.4 & 16.4 & 14.9 & 84.2 & 13.3 & 17.8 \\
\hline 1.99 & 7.0 & 81.8 & 34.8 & 7.0 & 8.7 & 80.1 & 15.5 & 15.9 & 14.8 & 84.4 & 14.6 & 18.4 \\
\hline 2.26 & 7.1 & 83.6 & 28.0 & 8.3 & 9.3 & 85.6 & 10.9 & 14.9 & 13.2 & 89.8 & 10.8 & 16.5 \\
\hline 2.35 & 8.7 & 85.4 & 30.5 & 8.6 & 10.2 & 86.2 & 11.4 & 13.3 & 13.8 & 87.9 & 11.2 & 18.3 \\
\hline 2.50 & 7.8 & 83.6 & 26.5 & 9.7 & 10.0 & 85.8 & 10.7 & 15.8 & 14.4 & 88.4 & 10.2 & 18.7 \\
\hline 2.57 & 7.4 & 81.8 & 29.1 & 7.9 & 8.3 & 82.7 & 13.1 & 16.1 & 12.1 & 85.7 & 13.2 & 17.5 \\
\hline
\end{tabular}


Table 1 lists the cows on the hay + sugar beet pulp diet (numbers 50-54) and the cows on the hay+swede diet (numbers 55-62). In this Table as well as in the following ones the cows are placed according to their food consumption. Table 1 shows also some data of the chemical composition of the ration (the whole food combination). The hay used was timothy with some red clover. The crude protein percentage of the hay dry matter varied $7.2-11.6$, the lignin percentage $8.7-10.0$, and the membrane substance percentage $57.9-64.7$. The dry matter of sugar beet pulp consisted of $13.1 \%$ crude protein, $1.7 \%$ lignin, and $37.2 \%$ membrane substances. The corresponding figures for the dry matter of swedes were $11.8 \%, 1.0 \%$, and $7.6 \%$, respectively. The amounts of fresh contents of the different parts of the digestive tract are given in Table 2. Tables 3a and 3b show the figures indicating the composition of the contents of the different parts of the digestive tract as well as of the faeces.

Table 4. The mean retention time of different food constituents in the reticulo-rumen.

The mean retention time of lignin in the whole digestive tract.

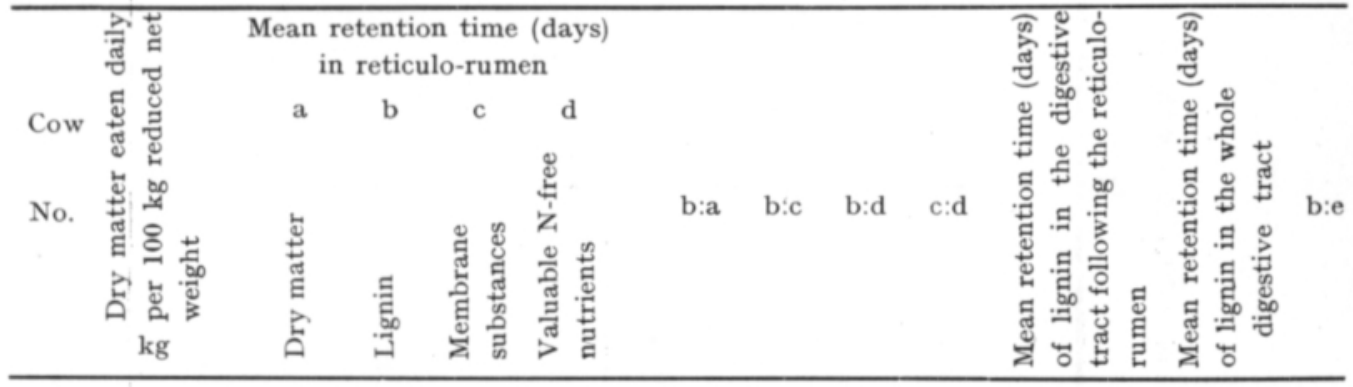

Cows fed on hay and sugar beet pulp

$\begin{array}{lllllllllllll}50 & 1.38 & 1.46 & 2.87 & 1.66 & 0.80 & 1.97 & 1.73 & 3.59 & 2.08 & 1.31 & 4.18 & 0.69 \\ 51 & 1.38 & 1.17 & 2.21 & 1.37 & 0.67 & 1.89 & 1.61 & 3.30 & 2.04 & 1.11 & 3.32 & 0.67 \\ 52 & 1.84 & 0.98 & 1.88 & 1.13 & 0.57 & 1.92 & 1.66 & 3.30 & 1.98 & 0.59 & 2.47 & 0.76 \\ 53 & 1.88 & 0.96 & 1.76 & 1.04 & 0.62 & 1.83 & 1.69 & 2.84 & 1.68 & 0.77 & 2.53 & 0.70 \\ 54 & 1.90 & 1.08 & 2.18 & 1.15 & 0.72 & 2.02 & 1.90 & 3.03 & 1.60 & 0.72 & 2.90 & 0.75\end{array}$

Cows fed on hay and swedes

$\begin{array}{lllllllllllll}55 & 1.85 & 0.87 & 1.69 & 1.09 & 0.44 & 1.94 & 1.55 & 3.84 & 2.48 & 0.46 & 2.15 & 0.79 \\ 56 & 1.88 & 1.05 & 1.86 & 1.38 & 0.48 & 1.77 & 1.35 & 3.88 & 2.88 & 0.77 & 2.63 & 0.71 \\ \left.57^{1}\right) & 1.92 & 0.93 & 2.02 & 1.30 & 0.41 & 2.17 & 1.55 & 4.93 & 3.17 & 0.67 & 2.69 & 0.75 \\ \left.58^{1}\right) & 1.99 & 0.81 & 1.77 & 1.15 & 0.36 & 2.19 & 1.54 & 4.92 & 3.19 & 0.57 & 2.34 & 0.76 \\ 59 & 2.26 & 0.82 & 1.40 & 1.14 & 0.34 & 1.71 & 1.23 & 4.12 & 3.35 & 0.51 & 1.91 & 0.73 \\ 60 & 2.35 & 0.87 & 1.56 & 1.12 & 0.43 & 1.79 & 1.39 & 3.63 & 2.60 & 0.38 & 1.94 & 0.80 \\ 61 & 2.50 & 1.00 & 1.79 & 1.30 & 0.48 & 1.79 & 1.38 & 3.73 & 2.71 & 0.46 & 2.25 & 0.80 \\ 62 & 2.57 & 0.79 & 1.48 & 1.01 & 0.39 & 1.87 & 1.47 & 3.79 & 2.59 & 0.34 & 1.82 & 0.81\end{array}$

${ }^{1}$ Swedes given in relatively larger quantities than to other experimental animals. 


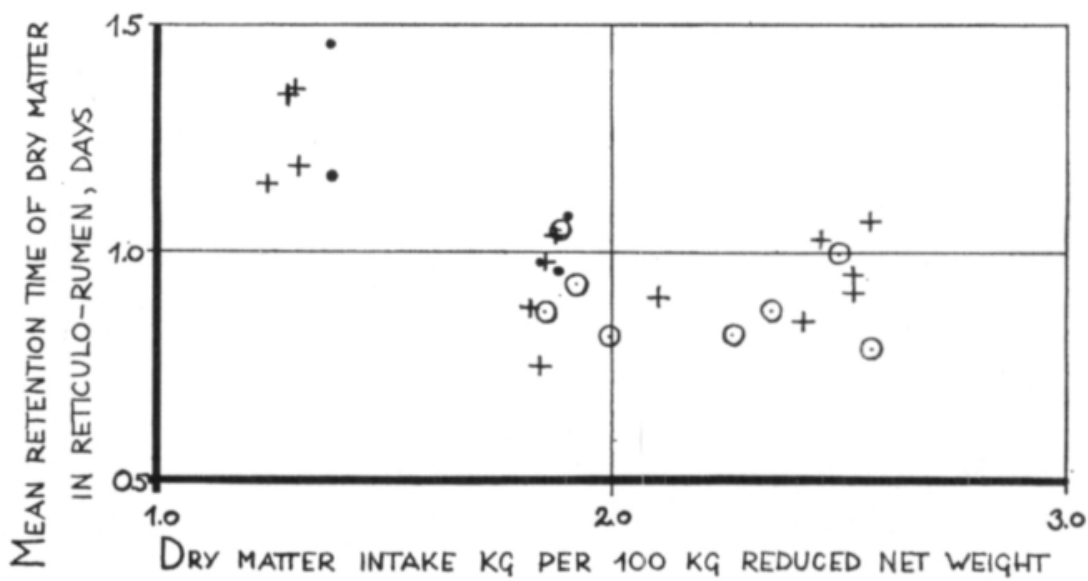

Fig. 1. Relationship between the dry matter intake and the mean retention time of dry matter in the reticulo-rumen. The dots refer to cows fed on hay and sugar beet pulp, dots enclosed in circles to cows fed on hay and swedes, crosses to cows fed on hay and concentrates.

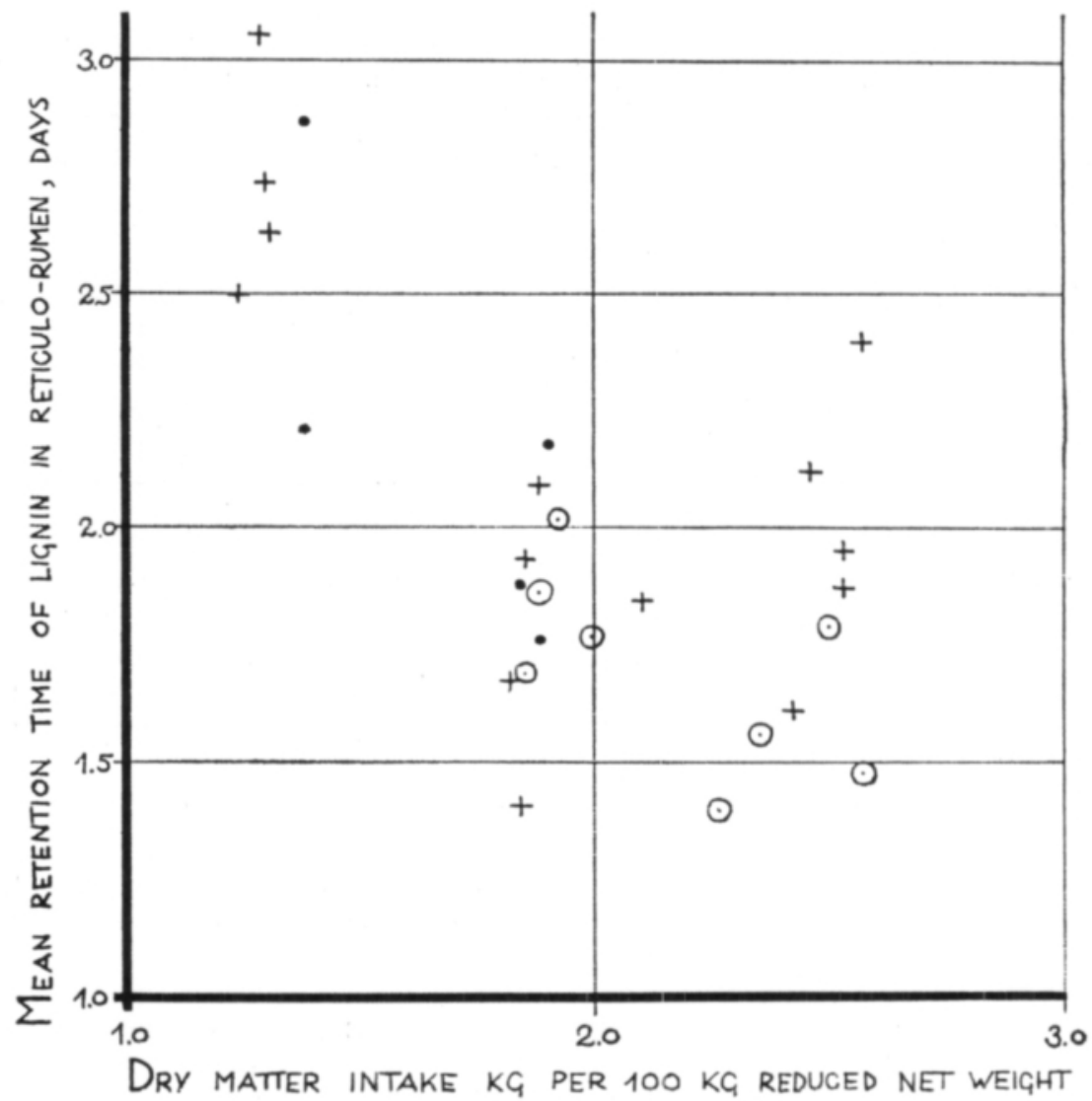

Fig. 2. Relationship between the dry matter intake and the mean retention time of lignin in the reticulorumen. The dots refer to cows fed on hay and sugar beet pulp, dots enclosed in circles to cows fed on hay and swedes, crosses to cows fed on hay and concentrates. 


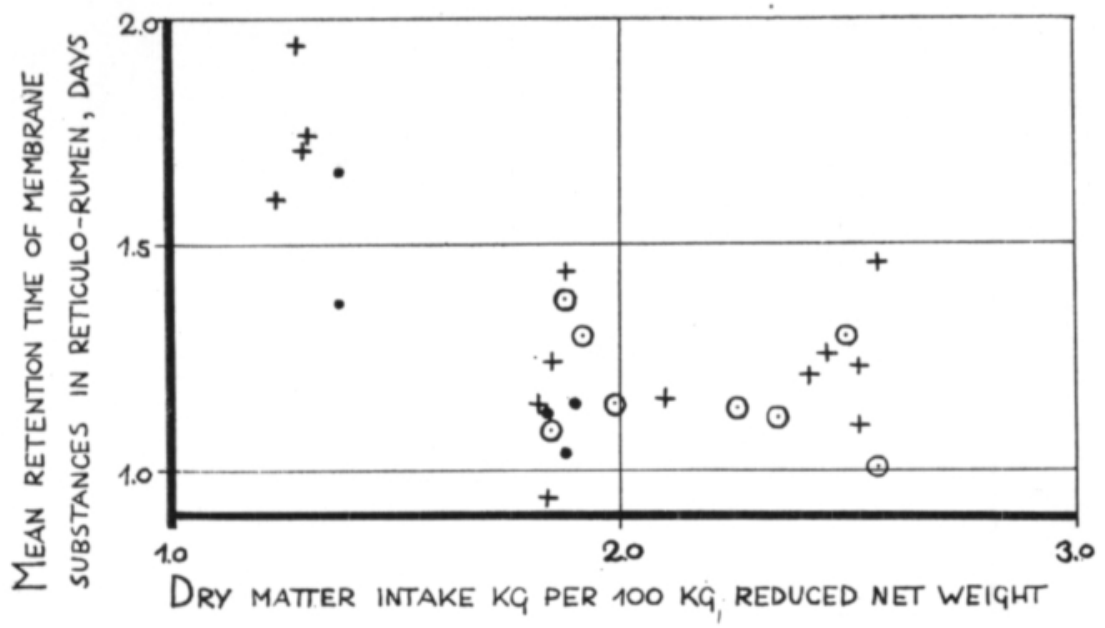

Fig. 3. Relationship between the dry matter intake and the mean retention time of membrane substances in the reticulo-rumen. The dots refer to cows fed on hay and sugar beet pulp, dots enclosed in circles to cows fed on hay and swedes, crosses to cows fed on hay and concentrates.

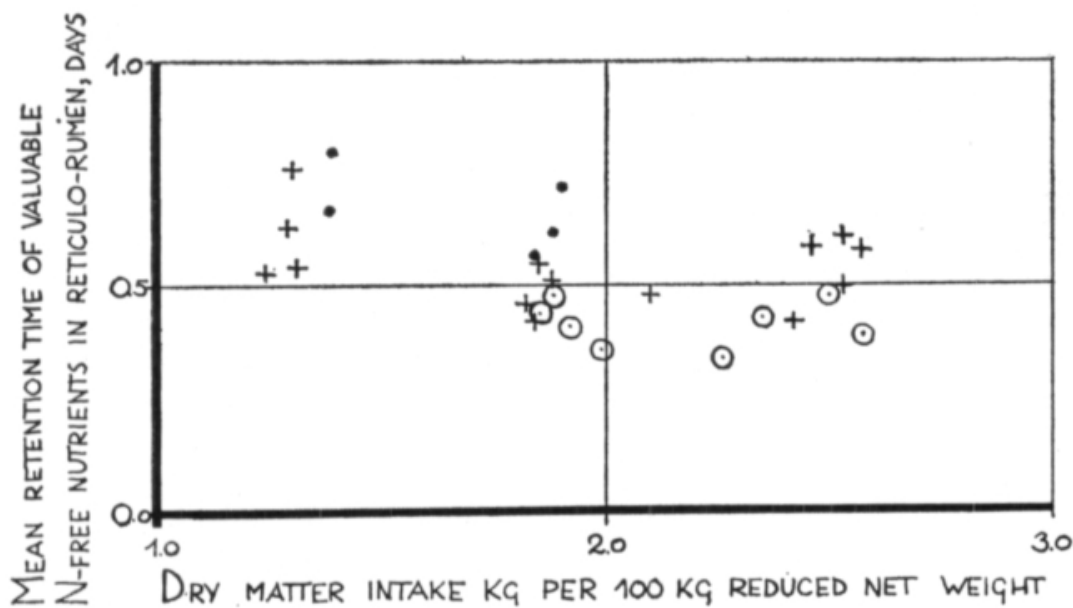

Fig. 4. Relationship between the dry matter intake and the mean retention time of valuable $\mathrm{N}$-free nutrients in the reticulo-rumen. The dots refer to cows fed on hay and sugar beet pulp, dots enclosed in circles to cows fed on hay and swedes, crosses to cows fed on hay and concentrates.

Table 4 shows the mean retention times for dry matter, lignin, membrane substances, and valuable $\mathrm{N}$-free nutrients in the reticulo-rumen as well as the mean retention time for lignin in the whole digestive tract and in the digestive tract following the reticulo-rumen. The following retention time ratios in the reticulorumen have been calculated: lignin: dry matter (b:a), lignin: membrane substances (b:c), lignin: valuable $\mathrm{N}$-free nutrients (b:d), and membrane substances: valuable $\mathrm{N}$-free nutrients (c:d). The quotas of the retention time of lignin in the reticulorumen and of its retention time in the whole alimentary canal are also given (b:e). 


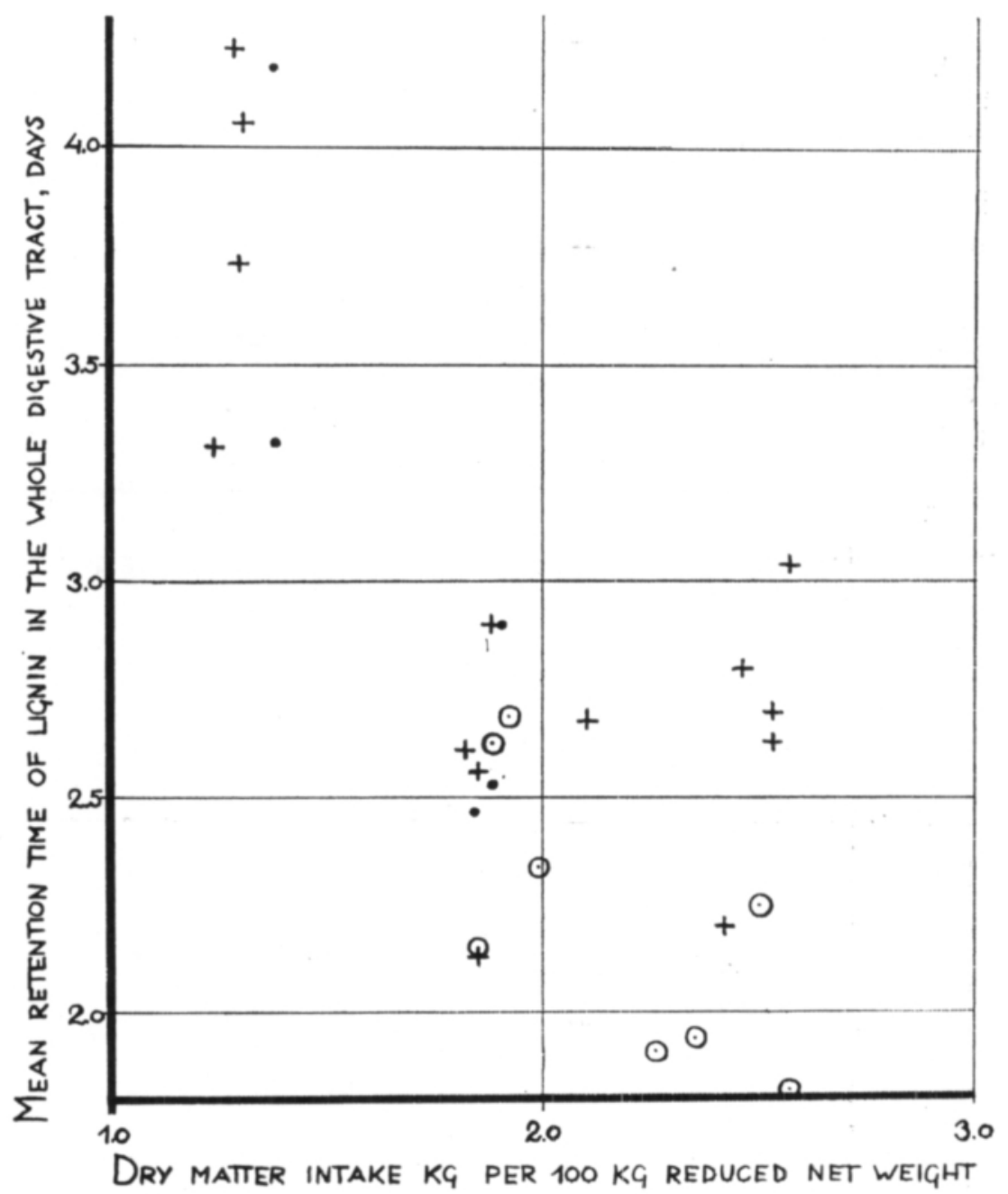

Fig. 5. Relationship between the dry matter intake and the mean retention time of lignin in the whole digestive tract. The dots refer to cows fed on hay and sugar beet pulp, dots enclosed in circles to cows fed on hay and swedes, crosses to cows fed on hay and concentrates.

Using data presented in Table 4 and in an earlier paper (3, Table $4 \mathrm{~b})$ figures $1-6$ have been drawn. Fig. 1 refers to the dry matter, fig. 2 to the lignin, fig. 3 to the membrane substances, and fig. 4 to the valuable $\mathrm{N}$-free nutrients in the reticulo-rumen. Fig. 5 pertains to the lignin in the whole alimentary canal, and fig. 6 to lignin in the alimentary canal following the reticulo-rumen. The retention times are plotted against the dry matter intake per $100 \mathrm{~kg}$ reduced net weight.

\section{Comparisons of retention times on the different diets}

The retention time of food in the digestive tract of cows fed on hay +sugar beet pulp can be compared with that of cows fed on hay+concentrates only when 


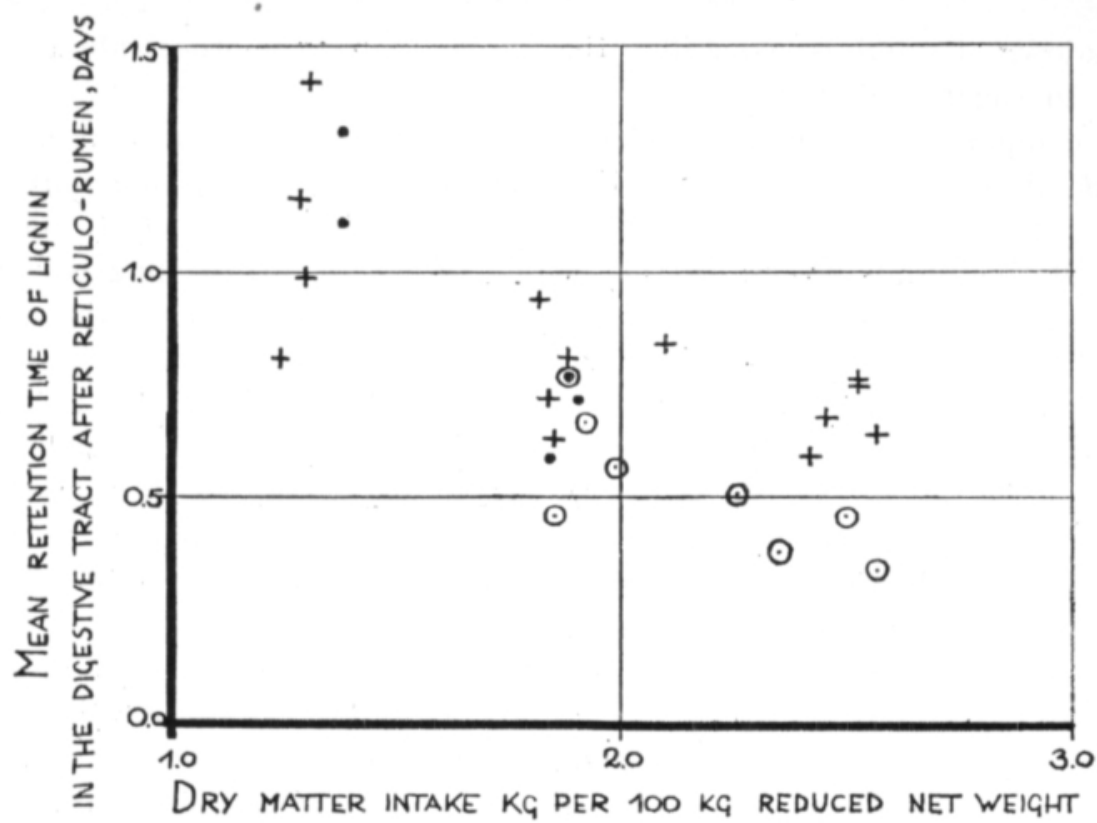

Fig. 6. Relationship between the dry matter intake and the mean retention time of lignin in the digestive tract following the reticulo-rumen. The dots refer to cows fed on hay and sugar beet pulp, dots enclosed in circles to cows fed on hay and swedes, crosses to cows fed on hay and concentrates.

the feeding level is scanty or medium abundant. Figures $1-6$ show that on both diets the retention times calculated decrease when the feeding level increases from scanty to medium abundant. This was statistically significant (at least $\mathrm{P}<0.05$ ) except in the case of valuable $\mathrm{N}$-free nutrients.

Figures 1, 2, 5, and 6 show that the mean retention times of dry matter and lignin in the reticulo-rumen as well as the retention times of lignin in the whole digestive tract and in the digestive tract following the reticulo-rumen are of the same magnitude on both diets. This holds true also of the retention times of lignin in the omasum, abomasum, and the intestines.

The mean retention time of membrane substances in the reticulo-rumen seems to be, though not statistically significant, shorter on a hay + sugar beet pulp diet than on the hay+concentrate diet (fig. 3). This may be due to the fact that on the former diet a considerable part of the membrane substances consisted of the almost lignin-free and thus readily hydrolysable membrane substances of the beet pulp.

Fig. 4 shows that in contrast the mean retention time of valuable $\mathrm{N}$-free nutrients in the reticulo-rumen is longer (about 0.1 days) on a hay + sugar beet pulp diet than on a hay + concentrate $\operatorname{diet}(\mathrm{P}<0.02)$. At least half of the said substances in the whole ration belonged either to concentrates or sugar beet pulp. The valuable $\mathrm{N}$-free nutriens in the concentrate are principally starch but those in sugar beet pulp consist largely of pectin. (According to the analysis made in this department the dry matter of beet pulp contained about $17 \%$ polyuronic acids). Apparently 
the breakdown of starch is faster than that of pectin and the other valuable $\mathrm{N}$-free nutrients in sugar beet pulp.

The comparison of retention times between the hay+swede and the hay+ concentrate diets can be made only at the medium abundant and abundant feeding levels. Fig. $1-6$ show that the retention times pertaining to the hay + concentrate diet are relatively independent of the feeding level if scanty feeding is excluded. If the scanty feeding is included, however, the relationships between the retention times and the amounts of dry matter eaten are curvilinear (primarily hyperbola), which is more evident from an earlier paper (3, p. 19). Figs. 1, 3, and 4 show that the mean retention times of dry matter, membrane substances, and valuable $\mathrm{N}$-free nutrients in the reticulo-rumen on a hay +swede diet are also rather independent of the feeding level varying from medium abundant to the abundant level. The retention times of lignin (figs, 2, 5, and 6), however, are shorter at the abundant than at the medium abundant feeding level $(\mathrm{P}<0.05)$.

Figs. 1 and 3 show that the mean retention times of dry matter (on an average 0.9 days) and membrane substances (on an average 1.2 days) in the reticulo-rumen are very similar on both diets. Also the retention times of lignin in the reticulorumen and in the whole digestive tract (figs. 2 and 5) are rather similar on both diets at the medium abundant feeding level. At the abundant feeding level, however, the said retention times on a hay + swede diet are shorter than on a hay+concentrate diet $(\mathrm{P}<0.05)$.

There is a significant difference between both diets in the retention times of lignin in the digestive tract following the reticulo-rumen $(\mathrm{P}<0.001)$. On the hay+ concentrate diet the said retention time was on an average 0.7 days and on a hay+ swede diet only 0.5 days. On the former diet the mean retention time of lignin was in the omasum as well as in the large intestine about 0.3 days. The corresponding figure pertaining to the latter diet was about 0.2 days. On both diets the said retention time in the abomasum and the small intestine separately was 0.07 days or 1.7 hours. The difference between the two diets in the retention times of lignin in the omasum and the large intestine may be due to the laxative effect of swedes at least when fed together with roughage. (It should be mentioned that the swedes used in the experiments were washed.)

Contrary to the situation on a hay+sugar beet pulp diet, the mean retention time of valuable $\mathrm{N}$-free nutrients in the reticulo-rumen was shorter on a hay+ swede diet than on a hay + concentrate $\operatorname{diet}(\mathrm{P}<0.01)$. The said retention time was on a hay + swede diet about 0.4 days and on a hay + concentrate diet 0.5 days. The main part of the valuable $\mathrm{N}$-free nutrients of the diets pertained to either swedes or concentrates. In swedes the said nutrients principally consist of sugars. According to the analysis made in this department $54 \%$ of the dry matter of swedes consist of sugars (mainly glucose and fructose), $9 \%$ of polyuronic acids, $3 \%$ of crude fat, and $8 \%$ hemicelluloses which fractions, excluding at least a part of the last mentioned, belong to the valuable $\mathrm{N}$-free nutrients. The said nutrients in concentrates used in the experiments are mainly starch. The difference in the retention times is in concordance with the observations of PHILlipson and Mc Anally (5, p. 199) who, using the fistula method in sheep, observed that the fer- 
mentation of sugars (glucose, fructose, and cane sugar) takes place more rapidy than that of starch.

The comparison of the retention times on hay + sugar beet pulp with those on a hay + swede diet is possible only at the medium abundant feeding level. There are no noticeable differences in the retention times of dry matter and lignin (figs. 1, 2, 5, and 6). The mean retention time of membrane substances has a tendency to be lower $(\mathrm{P}<0.2)$ and that of valuable $\mathrm{N}$-free nutrients is noticeably higher on a hay + pulp diet than on a hay + swede diet, the difference being for the latter retention time about 0.2 days $(\mathrm{P}<0.01)$. On the former diet this time was on an average about 0.6 days and on the latter diet 0.4 days.

Because of very small variations in consumed dry matter on some diets only a limited comparison of the retention times on the three diets discussed in this paper with those on only a hay diet discussed in earlier papers $(1$, p. $84 ; 3)$ can be made. It seems that the substituting of a certain amount of hay with concentrates, sugar beet pulp or swedes on a dry matter basis has no noteworthy effect on the mean retention time of dry matter in the reticulo-rumen. However, the mean retention time of lignin in the reticulo-rumen and in the whole digestive tract seems to increase except on the hay + swede diet. Also the retention time of the membrane substances seems to increase except on a hay+sugar beet pulp diet. The mean retention time of valuable $\mathrm{N}$-free nutrients, on the contrary, seems to fall except on a hay+sugar beet pulp diet. The retention time of lignin in the digestive tract following the reticulo-rumen seems to be uninfluenced by the diet with the exception of a hay + swede diet, on which the said retention time decreases.

It can be seen that replacing a part of the hay by more concentrated foods seems to have a retarding effect on the disappearance of the typical hay constituents (lignin as well as the total membrane substances) from the reticulo-rumen and an accelerating effect on the disappearance of valuable $\mathrm{N}$-free nutrients characteristic of concentrated foods. As shown earlier (3, p. 20) this may be due to the relatively rapid disappearance of concentrated foods from the reticulo-rumen. The result is the same as is obtained from the decreasing of the hay ration in experiments where hay was the only food. Regarding the hay + sugar beet pulp and the hay + swede diets this result was not so $€$ vident as in the case of the hay + concentrate diet. This may be due to the intermediate filling effect of the sugar beet pulp and swedes between the hay and concentrates (1, p. 108).

The ratios between the different retention times (Table 4) seem to be uninfluenced by the amounts of dry matter eaten. The same applied also to the hay and the hay + concentrate diets. The ratios are, however, highly dependent on the quality of the diet. Concerning the reticulo-rumen the quotient (retention time of lignin): (retention time of dry matter) varies $1.8-2.0$ on a hay + sugar beet pulp diet and $1.7-1.9$ on a hay + swede diet if the two values are omitted belonging to the cows that received relatively high amounts of swedes (numbers 57 and 58). The quotients are intermediate to the values pertaining to the hay and the hay + concentrate diets. The quotient (retention time of lignin): (retention time of membrane substances) is on hay + sugar beet pulp of the same magnitude as on the hay and hay + concentrate diets, 1.6-1.9. On the hay + swede diet it was lower, only 
$1.2-1.5$, owing to the relatively short retention time of lignin on a hay + swede diet. The quotient (retention time of lignin): (retention time of valuable $\mathrm{N}$-free nutrients) was on the hay + swede diet, if the values of cows numbers 57 and 58 are omitted, of the same magnitude as on the hay + concentrate diet, 3.6-4.1. On the hay + sugar beet pulp diet it was lower, 2.8-3.6, thanks to the relatively high retention time of valuable $\mathrm{N}$-free nutrients. The quotient (retention time of membrane substances): (retention time of valuable $\mathrm{N}$-free nutrients) on the hay + sugar beet pulp diet varies $1.6-2.1$ and on the hay + swede diet $2.5-3.4$. On the former diet it is lower and on the latter diet higher than on a hay + concentrate diet depending on the differences in the retention time of valuable $\mathrm{N}$-free nutrients.

The quotient (retention time of lignin in the reticulo-rumen): (retention time of lignin in the whole digestive tract) is on a hay + sugar beet pulp diet about 0.7 or the same as on the hay and hay+concentrate diets. On the hay + swede diet this quotient is about 0.8 in six cases and 0.7 in only two cases. This result is due to the relatively rapid passage of undigestible substances in the digestive tract on a hay + swede diet.

\section{$S u m m$ ary}

The retention times of dry matter and its constituents in the digestive tract of cows on hay + sugar beet pulp ( 5 cows) and cows fed on hay + swedes ( 8 cows) are compared with the retention times pertaining to cows fed on hay + concentrate or hay only. The following conclusions were reached:

On a hay + sugar beet pulp diet the mean retention time of dry matter in the reticulo-rumen, and the retention times of lignin in the reticulo-rumen, in the whole digestive tract, and in the digestive tract following the reticulo-rumen are of the same magnitude as the corresponding retention times on a hay + concentrate diet (figs. 1, 2, 5, and 6). The mean retention time of membrane substances in the reticulo-rumen seems to be shorter and that of valuable $\mathrm{N}$-free nutrients in the reticulo-rumen longer than the corresponding retention times on a hay + concentrate diet (figs. 3 and 4).

On a hay + swede diet the mean retention times of dry matter and membrane substances in the reticulo-rumen are of the same magnitude as on a hay + concentrate diet (figs. 1 and 3 ). The mean retention time of valuable $\mathrm{N}$-free nutrients in the reticulo-rumen and, in abundant feeding, the retention times of lignin in the reticulo-rumen, in the whole digestive tract, and especially in the digestive tract following the reticulo-rumen are shorter than on the hay + concentrate diet (figs. 2, 4,5, and 6).

On the hay + sugar beet pulp and the hay + swede diets the retention times are in general of the same magnitude. However, the retention time of membrane substances in the reticulo-rumen is shorter and that of the valuable N-free nutrients considerably longer on a hay + sugar beet pulp than on a hay + swede diet.

Replacing a certain amount of hay by concentrates, sugar beet pulp or swedes on a dry matter basis seems to have no effect on the mean retention time of dry 
matter in the reticulo-rumen. However, a retarding effect on the rate of passage of typical hay constituents (lignin and membrane substances) and an accelerating effect on that of valuable $\mathrm{N}$-free nutrients characteristic of concentrated foods was observed. The said replacing accelerates the rate of passage of lignin in the disgestive tract following the reticulo-rumen on a hay + swede diet.

Acknowledgements. The investigation has been supported by a grant from the State Science Commission (Valtion Luonnontieteellinen Toimikunta). I wish to acknowledge this grant with sincere gratitude.

\title{
R E F E R E N C E S
}

(1) MãKELÄ, A. 1956. Studies on the question of bulk in the nutrition of farm animals with special reference to cattle. Acta agr. fenn. 85: 1-130.

(2) PALOheimo, L. \& MäKelĩ, A. 1952. The rate of passage of food in the digestive tract of ruminants. J. Scient. Agric. Soc. Finland 24: 165-169.

(3) - $-\& \quad$ \& 1959. Further studies on the retention time of food in the digestive tract of cows. Acta agr. fenn. 94: 1-25.

(4) Paloheimo, L. \& Paloheimo, Irja 1949. On the estimation of the total of vegetable membrane substances. J. Scient. Agric. Soc. Finland 21: 1-16.

(5) Phillipson, A. T. \& Mc Anally, R. A. 1942. Studies on the fate of carbohydrates in the rumen of the sheep. J. Exp. Biol. 19: 199-214.

\section{SELOST U :}

\section{REHUN LAADUN VAIKUTUKSESTA REHUN VIIPYMISAIKAAN LEHMÄN RUOAN- SULATUSKANAVASSA}

\section{AARNe MÄKELÄ}

\author{
Kotieläintieteen laitos, Helsingin yliopisto
}

Rehun kuiva-aineen ja sen aineosien viipymisaikoja lehmän ruoansulatuskanavassa heinä- ja sokerijuurikasleike- sekä heinä- ja lantturuokinnoissa on verrattu viipymisaikoihin heinä- ja väkirehusekä yksinomaisessa heinäruokinnassa. Tällöin todettiin mm. seuraavaa:

Heinä- ja sokerijuurikasleike- sekä heinä- ja väkirehuruokinnoissa viipymisajat olivat suunnilleen yhtä pitkät paitsi, että edellisessä ruokinnassa kettoaineen keskimääräinen viipymisaika pötsiverkkomahassa oli lyhyempi ja typettömien arvoaineiden pitempi kuin jälkimmäisessä.

Heinä- ja lanttu- sekä heinä- ja väkirehuruokinnoissa kuiva-aineen ja kettoaineen keskimääräiset viipymisajat pötsi-verkkomahassa olivat suunnilleen yhtä pitkät. Typettömien arvoaineiden keskimääräinen viipymisaika pötsi-verkkomahassa sekä ligniinin viipymisaika, erityisesti ruoansulatuskanavassa pötsi-verkkomahan jälkeen, olivat edellisessä ruokinnassa lyhyempiä kuin jälkimmäisessä.

Heinä- ja sokerijuurikasleikeruokinnassa kettoaineen keskimääräinen viipymisaika pötsi-verkkomahassa näytti täten olevan lyhyempi ja typettömien arvoaineiden huomattavasti pitempi kuin heinä- ja lantturuokinnassa.

Heinän osittainen korvaaminen väkirehulla, sokerijuurikasleikkeellä tai lantulla kuiva-aineperustalla ei näytä vaikuttavan kuiva-aineen keskimääräiseen viipymisaikaan pötsi-verkkomahassa, mutta sensijaan näyttää yleensä pidentävän heinän tyypillisten aineosien (ligniini ja kettoaineet) viipymisaikaa ja lyhentävän väkeville rehuille ominaisten typettömien arvoaineiden viipymisaikaa pötsiverkkomahassa. Sulamattoman aineen (ligniinin) viipymisaika ruoansulatuskanavassa pötsiverkkomahan jälkeen oli heinä- ja lantturuokinnassa lyhyempi kuin muissa kokeilluissa ruokinnoissa. 